Article Revision

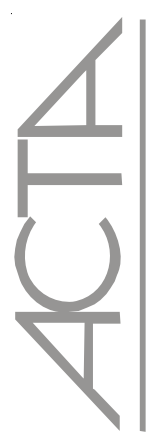

\title{
Integrative review of the clean and sterile technique: agreement and disagreement in the execution of dressing
}

\author{
Revisão integrativa da técnica limpa e estéril: consensos e controvérsias na realização de curativos
}

Revisión integrada de la tecnica limpia y esteril: consensos y controversias en la realización de curaciones

\author{
Adriano Menis Ferreira ${ }^{1}$, Denise de Andrade ${ }^{2}$
}

\begin{abstract}
Objective: This study aimed to describe, analyze, and categorize the evidence associated to the use of the clean and sterile technique in wounds. Methods: It is an integrative literature review using Lilacs, Medline and Cinahl databases. Results: Seven publications were found, of which four compare the clean and sterile technique, regarding the occurrence of infection; two evaluate the microbiological safety of gloves, and one analyzed the cleansing solution. Conclusion: There is consensus that the clean technique reduces costs. Considering the scarcity of studies, we stress the need to perform more level I and II research, according to the evidence hierarchy.
\end{abstract}

Keywords: Asepsis; Bandages/utilization; Surgical wound infection/nursing, Sterilization/methods

\section{RESUMO}

Objetivo: Analisar a literatura que descreve aspectos que envolvem a técnica limpa e estéril no cuidado de feridas. Métodos: Trata-se de uma revisão integrativa da literatura, nas bases de dados Lilacs, Medline e Cinahl. Resultados: Dentre as sete publicações identificadas, quatro compararam a técnica limpa e estéril do ponto de vista da ocorrência ou não de infecção; duas avaliaram a segurança microbiológica das luvas e uma analisou a solução de limpeza. Conclusão: É consenso que a técnica limpa reduz custos. Considerando a escassez de estudos, ressaltase a necessidade de mais pesquisas de níveis I e II, segundo a hierarquia de evidências.

Descritores: Assepsia; Bandagens/utilização; Infecção da ferida operatória/enfermagem; Esterilização/métodos

\section{RESUMEN}

Objetivo: Este estudio tiene como objetivo describir, analizar y categorizar las evidencias asociadas al uso de la técnica limpia y estéril en curaciones. Métodos: Se trata de una revisión integrada de la literatura en las bases de datos Lilacs, Medline y Cinahl. Resultados: Se tuvo un total de 7 publicaciones de las cuales 4 compararon la técnica limpia y estéril desde el punto de vista de la ocurrencia o no de infección; 2 evaluaron la seguridad microbiológica de los guantes y 1 analizó la solución de la limpieza. Conclusión: Es consenso que la técnica limpia reduce costos. Considerando la escasez de estudios se resalta la necesidad de más investigaciones de nivel I y II según la jerarquía de evidencias. Descriptores: Asepsia; Vendajes/utilización; Infección de herida operatoria/enfermería; Esterilización/métodos

\footnotetext{
${ }^{1}$ PhD. Professor of the Nursing Department - Universidade Federal do Mato Grosso do Sul-MS - Campus Três Lagoas

2 Associate Professor of the Department of General and Specialized Nursing - Universidade de São Paulo (USP) at Ribeirão Preto College of Nursing Ribeirão Preto (SP), Bražil.
} 


\section{INTRODUCTION}

Scientific and technological advancements demand specific knowledge and constant learning from health professionals in order to provide the highest quality of service.

The issue on a clean and sterile technique started in the 1970s, when Jack Lapides introduced the intermittent bladder catheterization concept with the clean technique. His work was considered audacious and groundbreaking by medicine and nursing professionals ${ }^{(1)}$.

The use of a sterile technique has been frequently questioned in many fields, including medicine ${ }^{(2-8)}$. Particularly regarding wound care, there is little agreement on using tweezers or procedure or sterile gloves; and concerning the type of solution and bandage*. The lack of research aiming to provide scientific evidence of these care practices certainly strengthens procedures based on myths and rituals.

Yet, basic nursing literature instruct to make a dressing from the cleaner to the most infected area, and, to reach this objective, sterilized tweezers should be used when removing the old dressing and making a new one ${ }^{(9-10)}$. Some nursing textbooks ${ }^{(9-14)}$ are unanimous in describing the dressing technique in sequential steps with their respective justifications emphasizing the wound infection control.

Within this context, advancements in microbiology, among other areas, have supported the recommendations of important and reputed organizations, such as the Agency for Healthcare Research and Quality, Association for Professionals in Infection Control and Epidemiology, Ostomy Continence Nurses Society, as well as many other studies ${ }^{(1,3,5,8,15-17)}$. Despite the expressive involvement of international entities, the indication of the clean and sterile technique remains controversial when performing many procedures, for instance, making dressings.

There appears to be an agreement on the execution of some asepsis practices, with both the clean and sterile technique. Asepsis, therefore, is defined as the reduction of the microbial infection of live tissues, fluids, or materials by eliminating, removing, or killing the microorganisms. The aseptic technique is a general expression used for asepsis methods ${ }^{(18)}$.

In general, the sterile technique involves practices that promote maximum reduction in microbial load by means of microorganism-free objects, such as: washing hands, using sterile fields, gloves, tools, and bandages.

* The term dressing is used to refer to the several products manufactured to treat wounds, regardless of becoming in touch with the wound bed or not. Bandage, however, refers to the process of wound care.
In this technique, it is possible to touch what is sterile with another sterile object or tool. Breaking the "barrier" or touching any other non-sterile surface or product should be avoided ${ }^{(19)}$.

Regarding the clean technique, the use of procedure gloves and sterile tools is recommended, in addition to asepsis principles, which includes environment and hands. Such technique can be called "non sterile" (18-19).

Considering the importance of an evidence-based practice, this study attempts to answer the following question: does the clean technique in dressings keep microbiologic safety, and, consequently, avoids predisposition to the risk of infection?

Therefore, the objective of this study was to analyze scientific articles that describe aspects regarding the clean and sterile technique on wound care.

\section{METHODS}

A literature review was performed using the database from Literatura Latino Americana em Ciências de Saúde (Lilacs), Medical Literature and Retrivial System on Line (Comprehensive Medline) and Cumulative Index to Nursing \& Allied Health Literature (Cinahl). All the articles associated to the use of clean and sterile techniques in dressings were analyzed, apart from their publication date. The keywords for obtaining these articles were: acute wound, chronic wound, clean technique and sterile technique.

The theoretical framework adopted was evidencebased practice (EBP), which emphasizes the use of research to guide clinic decision and requires learning specific skills for the different processes used to assess articles in an analytical and reflexive fashion. Therefore, the EBP combines research and the professional's clinic competence and the patient's preferences to make a decision about a specific problem ${ }^{(20)}$.

Evidence is defined as the presence of facts or signs that clearly show that something exists and is true, in other words, evidence is the proof or demonstration that this "thing" may legally be submitted to the assessment of the veracity of an issue ${ }^{(21-22)}$.

A six-level classification was proposed to assess the evidence from the studies ${ }^{(21)}$. This classification considers the methodological approach of the study, the outline used in the research and its strictness (Chart 1).

The systematic analysis of the articles involved: authorship, year, serial, objectives, outlining or design, and main results and recommendations.

\section{RESULTS}

In Lilacs and Cinahl databases, none of the articles 
Chart 1 - Evidence levels

\begin{tabular}{|l|l|}
\hline \multicolumn{1}{|c|}{$\begin{array}{c}\text { Evidence } \\
\text { Level }\end{array}$} & \multicolumn{1}{c|}{ Nature of the Study } \\
\hline Level I & Metanalysis of multiple controlled studies. \\
\hline Level II & Individual experimental studies (randomized clinic essay). \\
\hline Level III & $\begin{array}{l}\text { Quasi-experimental studies, such as the non-randomized clinic essay, unique group before and after } \\
\text { test, timing series or case control. }\end{array}$ \\
\hline Level IV & $\begin{array}{l}\text { Non-experimental studies, such as descriptive research, correlative and comparative, studies with } \\
\text { qualitative approaches and study cases. }\end{array}$ \\
\hline Level V & Assessing program data, data obtained in a systematic way. \\
\hline Level VI & Specialists' opinions, experience reports, agreements, regulations and legislations. \\
\hline
\end{tabular}

Source: Adaptation - Stetler CB, Morsi D, Rucki S, Broughton S, Corrigan B, Fitzgerald J, et al. Utilization-focused integrative reviews in a nursing service. Appl Nurs Res. 1998; 11(4):195-206 (21).

Chart 2 - Articles associated to the dressing technique, according to authorship, year, objectives, outline, evidence level, and main results.

\begin{tabular}{|c|c|c|c|}
\hline Authorship/year & Objective & Outlining/evidence level & Main Results \\
\hline $\begin{array}{c}\text { Sadowski et al., } \\
1988^{(3)}\end{array}$ & $\begin{array}{l}\text { To evaluate microbiological } \\
\text { safety of procedure gloves } \\
\text { for performing dressings in } \\
\text { burned units }\end{array}$ & $\begin{array}{c}\text { Exploratory Descriptive } \\
\text { Level IV }\end{array}$ & $\begin{array}{l}\text { The } 26(100 \%) \text { empty glove boxes present } \\
\text { some kind of bacteria; seven }(64 \%) \text { boxes } \\
\text { isolated } S \text {. aureus the ones presented in } \\
\text { patients' wounds. }\end{array}$ \\
\hline $\begin{array}{l}\text { Angeras et al., } \\
1992^{(23)}\end{array}$ & $\begin{array}{c}\text { To compare the use of } \\
\text { sterile saline solution and tap } \\
\text { water for cleaning traumatic } \\
\text { soft tissue wounds. }\end{array}$ & $\begin{array}{l}\text { Comparative non } \\
\text { randomized clinic essay } \\
\text { Level III }\end{array}$ & $\begin{array}{l}\text { The infection rate in the tap water group was } \\
5.4 \% \text { compared to } 10.3 \% \text { in the group } \\
\text { irrigated with sterile saline solution ( } \mathrm{p} \leq 0.05 \text { ); } \\
\text { decrease of } 50 \% \text { of costs in tap water group. }\end{array}$ \\
\hline Rossoff et al., 1993(5) & $\begin{array}{l}\text { To identify the kind, } \\
\text { density rate and pattern of } \\
\text { contamination in procedure } \\
\text { gloves in an intensive care } \\
\text { unit. }\end{array}$ & $\begin{array}{l}\text { Exploratory descriptive } \\
\text { Level IV }\end{array}$ & $\begin{array}{l}\text { The first } 16(55 \%) \text { pairs of gloves that were } \\
\text { aseptically donned were contaminated with } \\
\text { an average of } 1.8 \text { colony forming units. } \\
\text { The percentage of contamination and } \\
\text { microbial density did not significantly change } \\
\text { with the position of gloves in the Box } \\
\text { (beginning, middle and end). } \\
\text { The time of open boxes did not have any } \\
\text { relation with the contamination. }\end{array}$ \\
\hline Stotts et al.,1993(24) & $\begin{array}{l}\text { To investigate the practice } \\
\text { regarding the dressing } \\
\text { technique among the stomal } \\
\text { therapy nurses. }\end{array}$ & $\begin{array}{l}\text { Survey } \\
\text { Level IV }\end{array}$ & $\begin{array}{l}\text { Over } 80 \% \text { used the clean technique for } \\
\text { pressure and vascular ulcer care. } \\
\text { The cleanest technique was less used in } \\
\text { neonate patients. } \\
\text { Highest frequency of clean technique in } \\
\text { geriatric patients. } \\
\text { The clean technique was most used in long } \\
\text { term and home care. }\end{array}$ \\
\hline Wise et al., 1997(25) & $\begin{array}{l}\text { To evaluate the use of sterile } \\
\text { and procedures gloves in } \\
\text { wound care. }\end{array}$ & $\begin{array}{l}\text { Survey } \\
\text { Level IV }\end{array}$ & $\begin{array}{l}\text { Sterile gloves were generally chosen for deep } \\
\text { wounds with pus, tunnelized and exposed } \\
\text { fractures; procedure gloves for ulcer pressure } \\
\text { and whole surgical wound. } \\
\text { Home care nurses chose procedure gloves } \\
\text { with a higher frequency. }\end{array}$ \\
\hline Stotts et al., 1997(15) & $\begin{array}{l}\text { To evaluate the healing rate } \\
\text { and abdominal dehiscent } \\
\text { wounds costs, using the } \\
\text { clean and sterile technique } \\
\text { in dressings. }\end{array}$ & $\begin{array}{c}\text { Experimental randomized } \\
\text { clinic essay } \\
\text { Level II }\end{array}$ & $\begin{array}{l}\text { No statistically significant differences were } \\
\text { found in healing rates among the groups. } \\
\text { There was a cost decrease with the clean } \\
\text { technique. }\end{array}$ \\
\hline $\begin{array}{l}\text { Lawson et al., } \\
\qquad 2003^{(26)}\end{array}$ & $\begin{array}{l}\text { To evaluate the differences } \\
\text { in infection rates and costs } \\
\text { with the clean and sterile } \\
\text { technique in dressings. }\end{array}$ & $\begin{array}{l}\text { Descriptive, longitudinal } \\
\text { before-after } \\
\text { Level IV }\end{array}$ & $\begin{array}{l}\text { The infection rate three months before and } \\
\text { after the implementation of the clean } \\
\text { technique protocol was not statistically } \\
\text { significant. } \\
\text { There was a cost reduction with the clean } \\
\text { technique. }\end{array}$ \\
\hline
\end{tabular}


met the purpose of this study. In Medline, seven articles were found (Chart 2).

The themes of the articles were: occurrence of infection with the clean and sterile technique (4), microbiological safety of gloves (2) and cleansing solution (1).

The Chart 2 presents a synthesis of the articles included in the present integrative review.

\section{DISCUSSION}

The data from the present study were very useful for the beginning of discussions on the clean and sterile technique in dressings.

One study ${ }^{(25)}$ compared the clean and sterile technique in providing care to 30 patients with gastrointestinal surgeries that had their wounds healed secondarily. The subjects were divided into two groups of 15 patients each (clean and sterile technique) and studied from three to nine days. All of them had homogeneous variables. There were no statistical differences in the healing rate of the studied groups; there was only a reduction in the cost in the clean technique.

Regarding the solution used for cleaning wounds, a non-randomized clinic study ${ }^{(23)}$ with 617 patients with traumatic soft tissue wounds compared the use of sterile saline solution and tap water. The wounds were cleaned by means of irrigation with saline solution, for seven weeks, or with tap water for the same period. The nurses who analyzed the wounds did not know which solution was being used for wound cleaning. Despite the methodological fragility and considering that there was no description about the clean technique, among other confusing variables of this study, the incidence of infection in wounds irrigated with tap water was 5.4\% compared to $10.3 \%$ with sterile saline solution, for pd"0.05. Still, it presented a cost reduction of approximately $50 \%$ with tap water.

In the 1980s, there were some questions about the use of sterile and procedure gloves for routine care, such as changing dressings in burned patients. It is important to state that the literature is limited on the kind of gloves to wear and in non-invasive procedures ${ }^{(3)}$.

Therefore, there was an evaluation on whether the use of procedure gloves was safe enough in the burning unit, in non-invasive procedures, such as changing dressings. All the 26 boxes presented some kind of bacteria, inside or outside, and the highest incidence was the Staphylococcus aureus. This organism was found in seven $(64 \%)$ of the boxes and in the patients' wounds. In order to prevent crossed infection ${ }^{(3)}$ it suggests that the use of the same box for two or more patients should be avoided.

A study with stomal therapy nurses $(n=240)$ showed that over $80 \%$ used the clean technique for pressure and vascular ulcers, and $60 \%$ used it whatever the problem was (hypoxia, damaged perfusion, malnutrition, radiotherapy or immunosupression). The stomal therapy nurses used the clean technique the least in neonate patients $(38 \%)$ compared to pediatric patients $(60 \%)$. On the other hand, they used it in places of long term and home care $(73 \%)$ when compared to hospitalized patients (55\%). This explained the patients' instruction to perform the clean dressing technique when leaving the hospital. The global average of choosing the clean technique was $70 \%$, ranging from $55 \%$ to $80 \%$ with a median of $60 \%{ }^{(24)}$.

Another study used a questionnaire to evaluate the use of sterile and procedure gloves for wound care. This study involved 723 nurses in five different health care units, and emphasized on the variability of indications of sterile and procedure gloves in clinical practice. Sterile gloves, in general, were indicated for deep wounds, with pus, tunnelized and exposed fractures. Procedure gloves were indicated for changing pressure ulcer and whole surgical wound dressings. Moreover, when comparing community and hospital nurses, less than a third of those in charge of home care use sterile gloves (33\%) compared to hospital nurses $(80 \%)$. These indicators were influenced by the place of care, professional education and clinical experience ${ }^{(25)}$.

The aforementioned studies evaluated procedure gloves regarding their microbiota and compared the use of sterile and procedure gloves, in many clinical situations, with a view to find differences in the infection rate. Another research about microbial contamination was performed in 29 glove boxes. The first pairs, which were aseptically donned, presented an average contamination of 1.8 colony forming units, and the most frequent microorganism was the negative coagulasis Staphylococcus. The contamination rate and the microbiological density did not show significant changes with the position in the box. The routine use of gloves compared to the aseptic use increased the contamination rate in 11\% and microbial density with an average of 3.4 colony forming units per pair. The period that the boxes remained open was not associated with the contamination of the last aseptically donned pair. Half the pairs of gloves were sterile despite the constant contact of the professionals with the boxes.

The infection rate and the cost were evaluated ${ }^{(26)}$, in the clean and sterile technique in surgical wound dressings with healed secondary healing. The study was performed in two surgical units three months before and after implementation of the clean technique implementation. Before the implementation of the new technique, there were nine cases of surgical wounds. After three months using the clean technique, the infection rate was of eight wounds, which is not a statistically significant result. Another aspect shown in this study was the cost reduction.

Wound infection is one the major concerns of professionals who deal with this problem, not only due to 
the increase of trauma for the client but also because of the costs resulting from the infection process ${ }^{(27)}$. Thus, one may infer that what will determine wound healing is the interaction with the host rather than the presence of microorganisms ${ }^{(28)}$.

\section{CONCLUSION}

The evidence found is not sufficient to elaborate recommendations for clinical practice.

Sendo assim, a elaboração de pesquisas com delineamentos do tipo experimental contribuirá na tomada de decisão dos profissionais quanto à uniformização de condutas relacionadas à técnica limpa e estéril.

Therefore, experimental studies will contribute with professionals when they have to decide about the standardization of sterile and clean technique practices.

\section{REFERENCES}

1. Lapides J, Diokno AC, Silber SJ, Lowe BS. Clean, intermittent self-catheterization in the treatment of urinary tract disease. J Urol.1972; 107(3): 458-61.

2. Maitra AK, Adams JC. Use of sterile gloves in the management of sutured hand wounds in the A\&E department. Injury.1986; 17(3):193-5.

3. Sadowski DA, Pohlman S, Maley MP, Warden GD. Use of nonsterile gloves for routine noninvasive procedures in thermally injured patients. J Burn Care Rehabil. 1988; 9(6):613-5.

4. Berk WA, Welch RD, Bock BF. Controversial issues in clinical management of the simple wound. Ann Emerg Med.1992; 21(1):72-80. Comment in: Ann Emerg Med. 1992; 21(12):1516.

5. Rossoff LJ, Lam S, Hilton E, Borenstein M, Isenberg $\mathrm{HD}$. Is the use of boxed gloves in an intensive care unit safe? Am J Med. 1993; 94(6):602-7.

6. Burke FJ, Wilson NH. Non-sterile glove use: a review. Am J Dent. 1989; 2(5): 255-61.

7. Burke FJ. Use of non-sterile gloves in clinical practice. J Dent. 1990; 18(2):79-89. Review.

8. Giglio JA, Rowland RW, Laskin DM, Grenevicki L, Roland RW. The use of sterile versus nonsterile gloves during out-patient exodontia. Quintessence Int. 1993; 24(8):5435. Erratum in: Quintessence Int 1995; 26(8):533.

9. Alexandre NMC, Guirardello EB. Procedimentos básicos de enfermagem. São Paulo: Atheneu; 1995. Curativos; p.57-64.

10. KawamotoEE. Curativo.In:KawamotoEE, Fortes JI.Fundamentos de enfermagem.2a ed.São Paulo:EPU;1997.p.231-5.

11. Atkinson LD, Murray ME. Estabelecimento de um meio ambiente biologicamente seguro. In: Atkinson LD, Murray ME. Fundamentos de enfermagem: introdução ao processo de enfermagem. Rio de Janeiro: Guanabara Koogan; c1989. p.235-66.

12. Taylor C, Lillis C, LeMone P. Skin integrity and wound care. In: Taylor C, Lillis C, LeMone P. Fundamentals of nursing: the art and science of nursing care. $3^{\text {rd }}$ ed Philadelphia: Lippincott-Raven; 1997. p.899-946.

13. Craven RF, Hirnle C. Asepsis and infection control. In: Craven RF, Hirnle CJ, editors. Fundamentals of nursing: human health and function. 3rd. ed. Philadelphia: Lippincott Williams \& Wilkins; 2000. p.479-512.

14. Potter PA, Perry AG. Integridade cutânea e cuidado com feridas. In: Potter PA, Perry AG. Fundamentos de enfermagem. 5a ed. Rio de Janeiro: Guanabara Koogan; 2004. p.1319-94.

15. Stotts NA, Barbour S, Griggs K, Bouvier B, Buhlman L, WipkeTevis D, Williams DF. Sterile versus clean technique in postoperative wound care of patients with open surgical wounds: a pilot study. J Wound Ostomy Continence Nurs. 1997; 24(1):10-8.

16. Cheung LK, Chow LK, Tsang MH, Tung LK. An evaluation of complications following dental extractions using either sterile or clean gloves. Int J Oral Maxillofac Surg. 2001; 30(6):550-4.

17. Perelman VS, Francis GJ, RutledgeT,FooteJ, Martino F, Dranitsaris G. Sterile versus nonsterile gloves for repair of uncomplicated lacerations in the emergency department: a randomized controlled trial. Ann Emerg Med. 2004; 43(3):362-70.

18. Xavier G. "Asepsis". Nurs Stand. 1999; 13(36):49-53; quiz 55. Review.

19. Sussman C, Bates-Jensen BM, editors. Wound care: a collaborative practice manual for physical therapists and nurses. Gaithersburg, MD: Aspen Publishers; 1998.

20. Nobre MRC, Bernardo WM, Jatene FB. A prática clínica baseada em evidências. Parte I: questões clínicas bem construídas. Rev Assoc Med Bras (1992). 2003; 49(4): 445-9.

21. Stetler CB, Morsi D, Rucki S, Broughton S, Corrigan B, Fitzgerald $\mathrm{J}$, et al. Utilization-focused integrative reviews in a nursing service. Appl Nurs Res. 1998;11(4):195-206.

22. Galvão CM,SawadaNO,Rossi LA. A prática baseada em evidências: considerações teóricas para sua implementação na enfermagem perioperatória. Rev Latinoam. Enferm. 2002;10(5): 690-5.

23. Angeras MH, Brandberg A, Falk A, Seeman T. Comparison between sterile saline and tap water for the cleaning of acute traumatic soft tissue wounds. Eur J Surg. 1992; 158(6-7):347-50.

24. Stotts NA, Barbour S, Slaughter R, Wipke-Tevis D. Wound care practices in the United States. Ostomy Wound Manage. 1993; 39(3):53-5, 59-62, 64 passim.

25. Wise LC, Hoffman J, Grant L, Bostrom J. Nursing wound care survey: sterile and nonsterile glove choice. J Wound Ostomy Continence Nurs. 1997;24(3):144-50.

26. Lawson C, Juliano L, RatliffCR. Does sterile or nonsterile technique make a difference in wounds healing by secondary intention? Ostomy Wound Manage. 2003; 49(4): 56-8,60.

27. Bowler PG, Duerden BI, Armstrong DG. Wound microbiology and associated approaches to wound management. Clin Microbiol Rev. 2001;14(2):24469.

28. Dow G, Browne A, Sibbald RG. Infection in chronic wounds: controversies in diagnosis and treatment. Ostomy Wound Manage. 1999; 45(8):23-7, 29-40; quiz 41-2. 